\title{
Supporting Causes: Non-Profit Sponsorship of Gay Games IX
}

\author{
David Hack, PhD \\ William Paterson University \\ Department of Kinesiology \\ 300 Pompton Road, Wayne NJ 07470, USA
}

\begin{abstract}
Over the past three decades, sport sponsorship has played a significant role in the financial and operational success of sporting entities and events. While there has been dramatic growth in the numbers, complexities, and size of sponsorships, there are still large gaps in the literature regarding these multifaceted agreements. Little research has been executed regarding amateur sporting events, non-profit sponsorship agreements, and sponsorship of sport for members of the lesbian, gay, bisexual, and transgendered (LGBT) communities. Hence, this exploratory case study sought to investigate non-profit organizational sponsorships of the 2014 Gay Games, an amateur LGBT-focused sporting mega-event which garnered \$4.16 million dollars in sponsorships. Document collection and analysis, site observations, and semi-structured interviews were conducted with sponsorship decision-makers at six non-profit organizations in order to investigate this phenomenon. The first emergent theme indicated that non-profit sponsorship decision makers define sponsorship as support for a cause or event, a definition which differs from that found in much of the existing sport sponsorship literature. A second theme indicated that non-profit sponsorship was spurred by a desire to support diversity and inclusion. Finally, a third theme indicated that a desire to support education was also an important factor with regard to non-profit sponsorship of the 2014 Gay Games.
\end{abstract}

Keywords: sport sponsorship, Gay Games, non-profit, management

\section{Introduction}

Sponsorship has been defined a number of ways within the literature. Meenaghan's (1984) definition is widely cited within the sport management literature. He writes that sponsorship "can be regarded as the provision of assistance either financial or in-kind to an activity by a commercial organization for the purpose of achieving commercial objectives" (p.9). Sport sponsorship has undeniably become a significant component of the sport industry. The International Events Group (IEG, 2018) reports that's North American countries spent $\$ 16.26$ billion on sport sponsorships in 2017, a 3.6\% increase over 2016. They also forecast that 2018 spending would grow by $4.9 \%$ to $\$ 17.05$ billion, making it the $20^{\text {th }}$ consecutive year for sport sponsorship growth. Additionally, sport sponsorship dwarfs all other types of sponsorship with 2018 entertainment related sponsorships projected to be $\$ 2.4$ billion and sponsorship of the arts projected at $\$ 1.03$ billion. This monumental growth has allowed for sponsorship dollars to permeate the entire sport industry. Once reserved for professional sport, sponsorships have grown and evolved to make their impact felt at virtually all levels including youth, community, interscholastic, intercollegiate, and professional sport (Abratt, Clatyon\& Pitt, 1987; Dees, Bennett \& Villegas, 2008; Doherty, Misener \& Cuskelly, 2014; Stotlar, 2013).

Because of the monumental growth of sport sponsorship, practitioners and academicians have devoted a significant amount of time and effort to investigating these complex financial agreements. Efforts have been made to investigate corporate motivations, corporate objectives, consumer perceptions of sponsorship, and financial effects of sponsorship agreements. However, there is a scarcity of literature devoted to sponsorship of amateur sporting properties and almost no research dedicated to the sponsorship of LGBT focused sporting properties. Additionally, there is a limited but growing focus on sport sponsorships by the non-profit sector (Shani, 2015). Even so, a search of pertinent literature returned no existing study on non-profit sponsorship of LGBT themed amateur sport properties.

Therefore, the purpose of this study was to investigate the multi-layered phenomenon of non-profit sponsorship of the 2014 Gay Games, a quadrennial, international, LGBT focused sporting mega-event. Because of the existing gap in literature regarding non-profit sponsorship of LGBT themed sport, an exploratory case study method was employed. Case study research does not seek to establish reason and consequence, rather it aims to shed light on an emerging or evolving phenomenon. This study was guided by the following research question: Why did non-profit organizations engage in sponsorship of the 2014 Gay Games? 


\section{Literature Review}

\subsection{Sport Sponsorship}

Sandler and Shani (1993) write that "sport sponsorship is the provision of resources by an organization directly to an event or activity in exchange for a direct association to the event or activity" (p. 9). The roots of sport sponsorship can be traced to 65 B.C., when gladiators were sponsored in order to spur individual and political agendas (Head, 1981; Swaddling, 1999). The early days of sport sponsorship featured sponsorships born primarily of benevolent ideals (Wilkinson, 1993). However, the 1984 Olympic Games ushered in a new era of sport sponsorship, an era which has been credited as the true catalyst for corporate and organizational investment in sport sponsorship (Mullen, Hardy, \& Sutton, 2014). In this new era, sport sponsors have been predominantly focused on achieving a variety of businesscentric objectives such as increasing sales, increasing public awareness of products and services, enhancing company image, enhancing staff relations, blocking competition, and increasing market share (Irwin \& Asimakopoulos, 1994;Meenaghan, 1984; Mullen, Hardy, \& Sutton, 2014; Zullo, 2013). This is not to say that organizations have not been cognizant of the philanthropic impacts that their sponsorships may have, simply that it is predominately business based objectives that are the key driver in today's sponsorship market. While a great deal of research has focused on sport sponsorship motivations and objectives, this complex multi-faceted component of a company's marketing-mix has proven to be difficult to generalize. This study's qualitative, case study approach aims to allow for deep probing and analysis of this growing phenomenon.

\subsection{Non-profit Sport Sponsorship}

Cornell University's Legal Information Institute (n.d.) defines a non-profit organization as a group organized for purposes other than generating profits. Non-profit organizations act as a vital part of society, often working to improve society, benefit human welfare, and educate society on potential risks and hazards (Cadet \& Carroll, 2019). The nonprofit sector has demonstrated significant growth in the last several decades. The Johns Hopkins Center for Civil Society Studies (2018) reports that the non-profit sector added jobs at a rate of nearly four times that of the for-profit sector for the period of 2007-2016. Shani (2015) writes that as the non-profit sector grows more powerful and complex, leaders must consider adapting and adopting the successful business building practices of the commercial sector, which includes strategic partnerships and sponsorships. One way that the for-profit sector has been able to successfully build brand reputation is through sport marketing and sport sponsorship (Gwinner \& Eaton, 1999; Tsordia, Papadimitriou \& Parganas, 2018). While academia has begun to examine the non-profit sport sponsorship phenomenon, the response has been slow and focused largely on grassroots events (Shani, 2015). Furthermore, the vast majority of the work regarding non-profit sport sponsorship focuses on the non-profit sport organizations' quest for sponsorship (Berrett \& Slack, 2001; Wicker \& Breuer, 2012). The present study focuses on the motivations for nonprofit organizations engaging in sponsorship of a sporting property, the 2014 Gay Games.

\subsection{The Gay Games}

The Gay Games is a quadrennial sporting and cultural mega-event which promotes the acceptance of members of the lesbian, gay, bisexual and transgendered community and provides a safe and accommodating place for members of the LGBT community and their allies to engage in competitive sport. The Gay Games is organized by the Federation of Gay Games which exists to "foster and augment the self-respect of lesbian, gay, bisexual, transgender, and all sexuallyfluid or gender-variant individuals throughout the world and to promote respect and understanding from others, primarily by organizing and administering the international quadrennial sport and cultural event known as the "Gay Games"' (Federation of Gay Games, n.d., n,p.). The Gay Games began as the Gay Olympics, the vision of former U.S. Olympian Dr. Tom Waddell. Waddell created the event in response to negative observations and experiences as a sexual minority in the conventional sport setting (Litchfield, 2013). In 1982, more than 1,300 gay athletes descended on San Francisco for Gay Games I. Over the next three decades, the Games grew in both popularity and financial stature. Gay Games III took the event to an international location, as 7,300 athletes travelled to Vancouver, British Columbia to compete. In 2010, Gay Games VIII was held in Cologne, Germany. The event featured a budget of nearly $\$ 3.5$ million and an opening ceremony which welcomed 25,000 guests representing 70 countries (Symons, 2012).

\subsection{Gay Games IX}

On September 29, 2009, the Federation of Gay Games announced that the organizing group from Cleveland, Ohio had successfully bid for the opportunity to host Gay Games IX (Smith, 2009). Reactions within the LGBT community ranged from excitement, to shock, to disapproval (Maag, 2009; Smith, 2009). 
Many individuals questioned the decision, pointing to Ohio's lack of marriage equality and mandatory antidiscrimination protections for members of the LGBT community as explanations for their disappointment in the choice (Maag, 2009; Niedermier, 2015). Granting Cleveland, known around the world as a traditionally conservative and blue-collar city, the right to host the games represented a calculated risk on the part of the Federation of Gay Games officials (Magaw, 2014; Smith, 2009). Site-selection committee chair Darl Schaaff stated, "We've never really gone to the heartland. Here was an opportunity to boldly go to a place that is perhaps not recognizable throughout the world as a gay center, but where real change is starting to happen" (Maag, 2009, n.p.). Federation of Gay Games President Kurt Dahl echoed those sentiments, "We want to change people's perceptions through sports and culture. Cleveland is the one that really could help further that cause along" (Smith, 2009, n.p.). Cleveland's bid defeated competing bids from Boston and Washington, D.C. In August 2014, 10,000 LGBT athletes, allies, and their guests traveled to Cleveland to take part in Gay Games IX. Opening ceremonies were held at Quicken Loans Arena, home of the Cleveland Cavaliers, and featured a video welcome address from President Barack Obama. The event was featured an operating budget of $\$ 6.8$ million and accounted for a $\$ 52.1$ million economic impact in northeast Ohio (Rohlin \& Greenlaugh-Stanley, 2014). The event resulted in a profit of $\$ 147,000$, making the event the most profitable in Gay Games history (Suttell, 2015). \$4.16 million of the operating budget was obtained through cash and in-kind sponsorships of 193 corporations and organizations with the likes of Marriott, Ernst and Young, and United Airlines signing sponsorship agreements. Non-profit sponsorships accounted for a significant amount of funds raised through sponsorship agreements, highlighted by the event's first-ever presenting sponsorship deal (MaGaw, 2013).

\section{Method}

The purpose of this study was to investigate the phenomenon of non-profit sponsorship of the 2014 Gay Games. In compliance with university policy, the research question, a proposal summary, and pertinent forms were submitted to the Institutional Review Board and approval of exempt status was given. This study employed a qualitative methodology and an exploratory case study method in order to allow for a deep, probing investigation of the issue. Yin (2009) suggests exploratory case study as an appropriate research method when researching contemporary phenomena. This study was an empirical inquiry into the contemporary phenomena of non-profit sponsorship of a gay sporting mega-event in its "real-life context" (p. 13). Burns (1990) posits that case studies "have the aims of probing deeply and analyzing intensively" (p. 366) the many complex layers of the unit under study. Case studies provide the opportunity for "detailed contextual analysis" of events, conditions, and relationships (Zainal, 2007, p.1).

Figure 1

Case Study Research, adapted from Yin, 2009

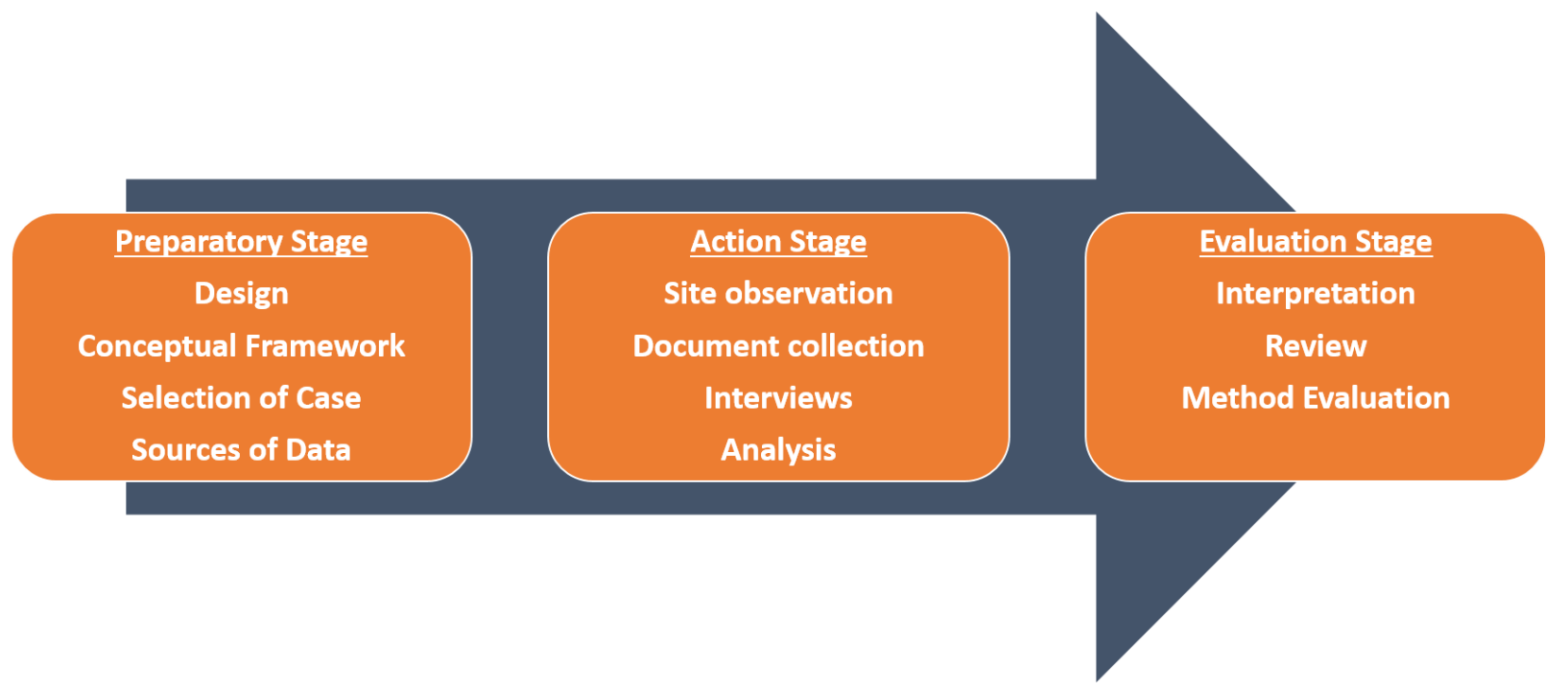

\subsection{Data Collection}

Case study research can extract evidence from up to six sources: archival records, direct observations, documents, interviews, participant observations, and physical artifacts (Yin, 2009) and are strengthened through the employment of multiple data sources (Yin, Bateman, \& Moore, 1993). This study garnered data through the employment of participant and site observation, document analysis, and in-depth semi-structured interviews. 
The researcher visited the $9^{\text {th }}$ installment of the Gay Games held in Cleveland, Ohio in August of 2014. A thorough and detailed observation journal was kept over the course of the event. Acting as a participant observer (Creswell, 2014; Yin, 2009) provided the chance to view sponsorship occurrence, activation, and reaction, provided an additional data source in order to triangulate and corroborate data, and allowed the researcher to experience and observe the phenomenon of Gay Games IX sponsorship in its real-life context. During and after the observation, public domain documents were collected from Gay Games events, the internet, and interview participants. After consulting practitioners, pertinent literature, and academicians, an 11 question interview guide was developed. The developed interview script was then used to guide in-depth semi-structured interviews with representatives of six non-profit organizations which sponsored Gay Games IX. Collection and analysis of data from multiple sources helped the researcher to establish credibility, transferability, dependability, and confirmability (Denzin \& Linclon, 2000; Merriam, 2009; Yin, 2009).

\subsection{Participants}

Qualitative methodology can employ a number of various participant sampling strategies (Creswell, 2014).After consultation with the literature, academic mentors, and practitioners, stratified random sampling was selected due to its ability to provide the highest probability of a representative sample (Gay, 1987; Mirakhmedov, Jammalamadaka, \&Ekstrom, 2015). Each sponsor of Gay Games IX was categorized into strata using the United States Small Business Administration guidelines. Strata were organized via Microsoft Excel and a randomized list of prospective participants was created. The researcher began contacting potential contributors from each stratum via email, social media, telephone, and internet contact forms and interviews continued until saturation (Glaser \& Strauss, 1967; Given, 2016) was reached. All potential participants were provided with a letter of introduction that outlined the research project and the parameters for participation. The informed consent document provided to participants included an explicit statement with regard to the voluntary nature of the research, as well as the right to withdrawal from the research. Representatives from six non-profit organizations engaged in semi-structured interviews at a time and location selected by the participants. Interviews ranged between 35 minutes and 80 minutes in length. The following table provides an overview of each of the participants, their assigned pseudonym, and organizational demographics.

\section{Table 1Participant and organizational demographics}

\begin{tabular}{|c|c|c|c|}
\hline Pseudonym & & Organizational Demographics & Industry Classification \\
\hline Jonathan & & Small, regional, non-profit & Professional and Technical Services \\
\hline Christopher & & Large, regional, non-profit & Educational Services \\
\hline Uriah & & Large, local, non-profit & Information \\
\hline Michael & & Small, regional, non-profit & Healthcare and Social Assistance \\
\hline Georgia & & Small, regional, non-profit & Healthcare and Social Assistance \\
\hline $\begin{array}{l}\text { Justine } \\
\text { Eleanor }\end{array}$ & and & Large, national, non-profit & Healthcare and Social Assistance \\
\hline
\end{tabular}

\subsection{Data Analysis}

Throughout the data collection and analysis phase, an inductive analysis transpired. This approach to analysis allowed the researcher to recognize emergent patterns and themes (Thomas, 2006; Yin, 2009). Data from documentary evidence, observation notes, and transcriptions of interviews were entered into NVivo 11 (QSR International, 2017) in order to organize, code, and construct themes. Microsoft Word and Microsoft Excel were also employed in order to assist with the creation of tables and organization of data. A constant comparison of data (Kolb, 2012) allowed for the emergence and development of codes, categories, and themes. Saldana (2012) writes that the excellence of research rests largely on the quality of coding. A code is defined as a "word or short phrase that symbolically assigns a summative, salient, essence-capturing... attribute for a portion of language-based or visual data" (Saldana, 2012, p. 3). Three rounds of coding occurred during the analysis phase: open coding, axial coding, and selective coding (Kolb, 2012; Thomas, 2006; Yin, 2009).

\section{Findings and Discussion}

In order to explore the subject of corporate sponsorship of gay sporting mega-events, seven individuals representing six non-profit organizations which sponsored Gay Games IX participated in semi-structured interviews. Further data were gathered via public domain documents including social media postings, press releases, and items collected during the field observation of Gay Games IX in August 2014, as well as researcher field notes and memos. Transcripts, the 42 documents accessed via public domain outlets, and field notes were initially coded manually and then entered into NVIVO 11 for further coding and analysis. 
Creswell (2014) writes that analysis is the process by which the researcher makes sense of data through the actions of dividing segments, labeling or coding the segments, and building related codes into themes. The data and identified themes were analyzed by several peers and colleagues in order to check for clarity, robustness, and potential bias. Through the process of data analysis, a number of themes emerged with regard to non-profit sponsorship of a gay sporting mega-event; those themes are presented below.

\subsection{Sponsorship as Support}

The concept of sponsorship as support emerged through an analysis of data. Participants and collected documents repeated the term "support" over and over again when referring to the Gay Games sponsorship agreement. Interview participants repeated the term on average 15.83 times during the course of the interview sessions. Public domain documents regarding non-profit sponsorship repeated the term 3.6 times on average. But beyond the mere repetition of the term, the statements made provided evidence that the decision makers within non-profit organizations take the consideration of sponsorships seriously, and likewise provide their support to sporting organizations very judiciously. Jonathan stated that the prominent nature of his organization's community presence, it was important to partner with the Gay Games, "With big community events such as this, we believe it is important to provide financial support." Uriah agreed that when major events happen in the community, his organization sees it as a responsibility to be supportive of those which can further the organization's mission. Christopher echoed those sentiments stating, "We define sponsorship as providing resources to an event or organization whose mission we support."

Michael spoke candidly about his organization's definition of sponsorship stating, "We define sponsorship as an avenue to participate in an event that we support that brings recognition to the organization. He went on, "We are very careful here, there are certain things that we can and cannot accept when we get a corporate sponsorships, so mainly we're just looking to overall support the event that we believe in." The concept of support was referenced by Michael a total of 27 times during the course of his interview.

When asked how her organization defined sponsorship, Georgia confirmed that the notion of support was at the forefront of consideration. "We defined sponsorship as supporting something through provision of our time or money." Later she expanded on the motivation for her organization's sponsorship or support of the Gay Games, "I think we're trying to support groups that do support in some way our mission which is to empower an inclusive community through various ways: education, outreach, and awareness, while eliminating stigma.

Justine and Eleanor spoke on behalf of their organization's support of Gay Games IX, and both referenced support as a significant consideration. As Justine shared, "This was an opportunity to support an inclusive event that was good for Northeast Ohio. It was a way for us to say not only do we support the Games, but we also support some of our employees who are involved in planning or competing." Eleanor added, "It was about being a good community partner and supporting the event, it was also about supporting the opportunity to either compete, or just come out as spectators."

Wilkinson (1993) writes that the early days of sponsorship featured sponsorship primarily born of philanthropic ideals; companies did not see sponsorship as an important factor in achieving their business objectives. More recently, sponsorship research has shown companies place an increasing importance on the financial return of investment (Lough, 2000; Mullen, Hardy, \& Sutton, 2014).Sport sponsorship has also evolved from its early foundations as a philanthropic act to a calculated corporate marketing tactic (Cobbs, 2011; Dolphin, 2003; Jensen and Cobbs, 2014; Lee, Hur, and Sung, 2015). Bennett (1977) writes that motivation is the driving force of behavior that causes individuals to act in a certain way so that needs will be fulfilled. As represented through their responses, the decision makers involved with sponsorship of Gay Games IX were motivated by a desire to support a cause for which they and their respective organizations felt a passion. Researchers have examined motivations for sport sponsorship from a variety of angles and noted a dramatic shift in philosophy of corporate sponsorship, moving from philanthropic motives in the 1960s and 1970s to motivations driven by business-centric objectives in the present day (Dolphin, 2003; Lough \& Irwin, 2001). The findings from this study however indicate that in concert with business-centric objectives, the desire to offer philanthropic support was an extremely significant consideration and motivator for non-profit sponsorship of Gay Games IX.

\subsection{Support for Diversity and Inclusion}

The desire to support an event which champions diversity and inclusion emerged as an extremely prevalent theme through an analysis of the available data. Participants as well as documents provided a great deal of information specifically addressing the importance of the Gay Games commitment to an inclusive environment. Christopher clearly stated the importance to his organization: It was the number one driving factor. 
Yes, we wanted to support an event like this that showcases Northeast Ohio and we loved the educational components of the event that fell in line with our mission, but most importantly we wanted to provide support for an event that celebrates diversity and the value in everyone regardless of athletic ability or sexuality. Several participants saw the opportunity for sponsorship to make a statement on the international level with regard to the push for equality. Making the decision to sponsor was easy for Georgia and her organization, "We knew we wanted to support the efforts, not only was it about sports, but it was also about diversity and inclusivity, which obviously we support."

Documentary evidence substantiated the importance of diversity and inclusion for non-profit sponsors. Susan Juris, President of University Hospitals stated, "Supporting the Gay Games is consistent with our commitment to nurture and strengthen a culture of diversity and inclusion" (The why, n.d.). We are a proud sponsor of Cleveland's LGBT community and of the 2014 Gay Games", shared Dr. Akram Boutros during his announcement of the partnership between the health system and GG9 (MetroHealth, 2014, p.1). As part of their sponsorship agreement, MetroHealth endowed a scholarship fund designed to increase Gay Games participation in under-represented groups. The fund was designed to encourage registration of the elderly, racial and ethnic minorities, and transgendered individuals. As Earle pointed out, "This was more than just about bringing athletes to Cleveland, it was about making a statement in a city that yes is very Democrat, but we're in Ohio, middle America." In the press release announcing their sponsorship agreement, Judge Mary Margaret Rowlands, chair of the Gay Community Endowment fund stated "The Gay Games coming here gives us the wonderful opportunity to show the world and our own neighbors what a strong and supportive LGBT and ally community we have" (Gynn \& Grafton, 2014, p.1).

Jonathan echoed those sentiments: It was a unique opportunity. The Gay Games hadn't been in cities the size of Cleveland before. We saw it as an opportunity to demonstration the kind of open and inclusive community we have in Cleveland and to take that message to other parts of the world. In addition to the opportunity to support an event that was devoted to creating an inclusive environment, some sponsors saw the opportunity to support Gay Games IX as the opportunity to encourage others to value diversity. Earle represented that sentiment stating "We wanted the Gay Games in Cleveland to make a statement, to open people's minds and hearts."

Similarly, Nicki shared: It was definitely very important for us. Over the last ten years or so, we've started to see development of the gay community around us come together and be more prevalent in the city. Years ago, it wasn't as open or welcome. With the Gay Games, the city really seemed to pull together. A lot of rainbows and a lot of happy people.... It was really a very intense event for Cleveland. I think it opened the eyes of a lot of people who didn't really understand what the Gay Games were all about or had their side comments about what was coming to Cleveland. But it actually showed them that you don't have to be gay to participate, you can be of any age and sexual persuasion. Physical activity and sport places have long been recognized as spaces where individuals could exert their own power and superiority (Plymire \& Forman, 2000). However, that dominance and superiority is rooted deeply in a heterosexist foundation (Cunningham, 2012) where hegemonic masculinity (Chenn \& Curtner, 2013; Swain, 2006) serves to stigmatize members of sexual minorities. Anderson (2002) writes that American sport spaces have too often marginalized gay athletes. The Gay Games provide the opportunity for LGBT athletes to be true to themselves, compete in their sports of choice, and feel safe and supported. The commitment by the Federation of Gay Games to promoting an inclusive and diverse world served as a tremendous motivator for non-profit organizations to engage in sponsorship. Respondents indicated the importance of the Games central mission of diversity and inclusion as "very critically important", "extremely important", and "a huge part of it". Sponsors realized that not only was the event about the various sporting competitions, but rather it was the opportunity to make a public statement on their organization's feelings and thoughts on rights and opportunities for the LGBT community. The sponsorship agreement provided organizations with the outlet to promote their organizations and communities as ones which valued diversity and inclusion. Finally, it provided the organizations with the public platform to challenge the existing sport power structures which laud heterosexist and heteronormative behaviors while stigmatizing and relegating LGBT individuals.

\subsection{Support for Education}

The educational value of the Gay Games emerged from data analysis as an important factor during consideration of Gay Games IX sponsorship. Many participants cited education as an impetus for engaging in support of the Games. The education provided by the event happened in two forms, one in formal educational settings such as a conference and several smaller seminars, and the second through spreading awareness of LGBT issues and challenging preconceived notions and biases; both were referenced as important considerations for event sponsors. Gay Games IX included a conference called "Game Change Conference" which acted as a professional development and educational conference dedicated to current issues facing the LGBT community. Georgia shared that the opportunity to provide support for the conference was an important reason for sponsorship by her organization: Sometimes people need something on their visa and depending on the country, they may not be able to identify that they are going to a gay event. We were excited to be able to support that effort while providing education to the community on LGBT issues. 
Uriah also identified the educational opportunities as a chief motivator for sponsorship, "The Gay Games had an educational component to it, and we wanted to leave a mark on the community as well as teach people about diversity." Jonathan also identified the importance of the educational element of Gay Games IX when discussing his organization's decision to sponsor Gay Games IX: When we first spoke about sponsoring the Games, there were some concerns raised about the Games and sports as a focus. But we looked at this sponsorship as the possibility to support something that was going to be educational and informative.

The Cleveland Clinic considers education to be an important component of their mission, vision, and values. The clinic's sponsorship of Gay Games IX included an initiative aimed at providing context and guidance for medical students and practitioners charged with providing care to LGBT athletes entitled "Treating the LGBT Athlete and Patient". The official Gay Games IX schedule described the conference as one, "for any provider who wants to improve their knowledge of LGBT healthcare disparities, barriers to quality care, and expand their skills and comfort in providing care for LGBT athletes and patients" (Event schedule, n.d). The conference included learning objectives which included reviewing barriers to quality care for LGBT patients and athletes, demonstrating cultural competency and professionalism in the treatment of LGBT patients, discussion of diseases threatening LGBT athletes, gaining resources for anti-bullying and LGBT healthcare.

Christopher spoke about the importance of education as a motivating factor for his organization's support stating, "We wanted people to see our name on a prominent educational event and associate us with quality, with education, with good." Michelle Tomallo, whose company was a member of Plexus, Cleveland's LGBT Chamber of Commerce, saw the sponsorship as an "opportunity to raise awareness of inclusivity and help create positive change" (Plexus, 2014). She also referred to the Games as a "chance to change hearts and minds." Nicki echoed those sentiments stating, "The Gay Games gave everybody an opportunity to participate in sport if they wanted to, whereas Cleveland gave the Gay Games the opportunity to come and show people who are not as open or accepting that they were a great group of people who deserved to be welcomed and supported." Georgia also recognized the potential the Games had to inform the general public: A lot of people hadn't heard of the Gay Games. They didn't know what it was about, they wondered if they had to be gay to participate. It was really an opportunity to talk to people about how we're all human and this is a celebration of how we are all humans at the core and then we have these other things that label us such as our orientation and gender identity. And so that's a good bit of what we do on a daily basis....we're trying to eliminate stigma. Part of eliminating stigma is education and exposure to how normal we all are as humans.

Data gathered from participant responses, document analysis, and observational field notes identify education as a significant factor which motivated non-profit sponsorship of the Gay Games. Non-profit sponsors were particularly interested in the Games ability to educate individuals on issues that directly impact the non-profit organization's own missions. Numerous decision-makers within non-profit organizations referenced the idea that by supporting the Gay Games, they were in fact contributing to the creation of an environment which would make it easier for their own operations and accomplishment of their own mission. This theme supports Zullo's(2013) findings that sponsors focus most heavily on sponsorship of programming which can result in significant returns. In the case of non-profits, those returns are in fact the accomplishment of mission. The Gay Games offered sponsors the opportunity to support formal education through a number of initiatives. Educationally based organizations found this to be an extremely significant component of the event and served to motivate involvement when many typically had avoided sport sponsorships in the past. Additionally, sponsors valued the ability for the Games to inform the general public on a variety of issues surrounding the LGBT community and to create a dialogue which could lead to advancements in understanding of the population and challenges its members face.

\section{Recommendations and Conclusion}

Non-profit organizations engaged in sponsorship of Gay Games IX because it gave those groups opportunities to support the promotion of diversity, inclusion, and education. This study served as an exploratory investigation into the complex phenomenon of non-profit sponsorship of LGBT themed sporting properties. With the historical growth of sport sponsorship and sporting organizations faced with budgetary constraints, it is more than reasonable to surmise that sponsorship of the Gay Games and similar events will continue to be valued by a variety of actors. Practitioners can use the information gleaned from this study in order to better tailor their solicitations of non-profit organizations. Academicians should continue to investigate this phenomenon through a variety of methods and lenses. The qualitative methodology employed for this study provided the chance for deep and evocative discourse regarding the phenomenon. The current study presents a methodologically sound template for further empirical research delving into the topic of sponsorships for stigmatized and marginalized populations as well as less studied areas of sport sponsorship. However, a mixed methods study using an established quantitative instrument while also integrating open ended questions could provide substantial amounts of pertinent data to add to the currently small knowledge base regarding the issue. 
A mixed methods study would provide both academicians and practitioners with a more complete and comprehensive understanding of the complex phenomenon of the non-profit sponsorship decision making process.

In conclusion, this study provided valuable information with regard to non-profit sponsorship of gay sporting megaevents. Shani (2015) implores non-profit organizations to replicate practices which have allowed corporate and forprofit organizations to flourish, and in some ways the findings from this study support the notion that non-profit organizations are doing just that. While they did not necessarily define sponsorship in the terms of rights and responsibilities emergent from many other sport sponsorship studies, the deep and probing nature of this qualitative inquiry did allow for a dialogue that revealed the decision makers to be mindful of supporting an event that allowed for each of their respective organizations to further their own causes. Whether it be furthering of social justice causes, health and well-being, education, or diversity and inclusion, the desire to support an event which championed a variety of important issues facing the LGBT community was paramount to decision makers. Ultimately these findings suggest that sponsorship of Gay Games IX was a complex and multi-layered process. However, as the existing literature indicates, sport sponsorship is a process which has experienced significant changes and evolution in a relatively short period of time. Additionally, sport sponsorship of gay sporting mega-events seems to be growing in popularity and significance. Gay sporting mega-events have grown tremendously both in scope as well as financial significance, as such, this is a phenomenon that sport and leisure researchers should continue to investigate through a variety of methods.

\section{References}

Abratt, R., Clayton, B., \& Pitt, L. (1987). Corporate objectives in sports sponsorship. International Journal of Advertising, 6(4), 299-312.

Bennett, T.L. (1977). Brain and behavior. Monterey: Brooks-Cole.

Berrett, T., \& Slack, T. (2001). A framework for the analysis of strategic approaches employed by non-profit sport organizations in seeking corporate sponsorship. Sport Management Review, 4, 21-45.

Burns, R. (1990). Introduction to research methods in education. Melbourne: Longman Cheshire.

Cadet, F., \& Carroll, R. (2019). Nonprofit organization communication: Risky business. Review of Business,39(1), 114.

Cobbs, J. (2011). The dynamics of relationship marketing in international sponsorship networks. Journal of Business and Industrial Marketing, 26(8), 590-601.

Cornell University Legal Information Institute. (n.d.). Nonprofit organization. Retrieved from https://www.law.cornell.edu/cfr/ text/2/25.34.

Creswell, J.W. (2014). Research Design: Qualitative, quantitative, and mixed methods approaches. London: Sage.

Dees, W., Bennett, G., \& Villegas, J. (2008). Measuring the effectiveness of sponsorship of an elite intercollegiate football program. Sport Marketing Quarterly, 17, 79-89.

Denzin, N., \&Lincoln, Y. (2000).Handbook of Qualitative Research. London: Sage.

Doherty, A., Misener, K., \&Cuskelly, G. (2014). Toward a multidisciplinary framework of capacity in community sport clubs. Nonprofit and Voluntary Sector Quarterly, 43(2s), 124s-142s.

Dolphin, R. (2003). Sponsorship: Perspectives on its strategic role. Corporate Communications: An International Journal, 8, 173-186.

Federation of Gay Games. (n.d.). What we do. Retrieved from https://gaygames.org/What-We-Do.

Gay, L.R. (1987). Educational research. Columbus: Merrill Publishing Company.

Given, L.M. (2016). 100 questions (and answers) about qualitative research. London: Sage.

Glaser, B., \& Strauss, A. (1967).The discovery of grounded theory: Strategies for qualitative research. Chicago: Aldine Publishing Company.

Gwinner, K., \& Eaton, J. (1999). Building brand image through event sponsorship: The role of image transfer. Journal of Advertising, 28(4), 47-57.

Gynn, A., \& Grafton, J. (2014). Gay Community Endowment Fund of Akron Community Foundation supports Gay Games at elite level. [Press release]. Retrieved from http://www.gg9cle.com/_CE/pagecontent/Documents/ News/NewsReleaseAkronGCEFSponsorship103013FINAL.pdf.

Head, V. (1981). Sponsorship. Cambridge: Woodhead-Faulkner.

International Events Group (2018). IEG sponsorship report: Volume 37. Chicago: IEG Inc.

Irwin, R. \&Asimakopoulos, M. K. \& Sutton, W. A. (1994). A model for screening sport sponsorship opportunities. Journal of Promotion Management, 2(3), 53-69.

Jensen, J.A., \& Cobbs, J.B. (2014) Predicting return on investment in sport sponsorship: 
Modeling brand exposure, price, and ROI in Formula One automotive competition. Journal of Advertising Research, 54(4), 435-447.

John Hopkins Center for Civil Society Studies. (2018). Nonprofit economic data project. Retrieved from http://ccss.jhu.edu/research-projects/nonprofit-economic-data/.

Lee, W.Y., Hur, Y., \& Sung, M. (2015). Happy to support: Emotion as a mediator in brand building through philanthropic corporate sponsorship. Social Behavior and Personality, 43(6), 977-992.

Litchfield, C. (2013). Female field hockey players and Gay Games participation. The International Journal of Sport and Society, 3(2), 13-24.

Lough, N. (2000). Corporate sponsorship of sport. Successful Sport Management, Durham, NC: Carolina Academic Press.

Lough, N. \& Irwin, R. L. (2001). A comparative analysis of sponsorship objectives for U.S. Women's sport and traditional sport sponsorship. Sport Marketing Quarterly, 10(A), 202-211.

Maag, C. (2009, October). Forget Chicago: Cleveland gets the Gay Games.Time. Retrieved from p://content.time.com/ tim e/nation/article/0,85 99,1927211,00.html.

Magaw, T. (2013, April 10). Cleveland Foundation Becomes Name Sponsor of 2014 Gay

Games. Crain's Cleveland Business. Retrieved from http://www.crainscleveland.com/article /20130410/FREE/130419977/cleveland-foundation-becomes-name-sponsor-of-2014-gay-games.

Magaw, T. (2014, July 20). Gay Games 9: Blue-collar Cleveland embraces progressive event, which could change area's image. Crain's Cleveland Business. Retrieved from http://www.crainscleveland.com/article/20140720/SUB1/140719786/gay-games-9-blue-collar-clevelandembraces-progressive-event-which.

Meenaghan, T.A. (1984). Commercial sponsorship. Bingley, United Kingdom: MCB University Press.

Merriam, S. (2009). Qualitative Research: A Guide to Design and Implementation. San Francisco: Jossey Bass.

MetroHealth. (2014). MetroHealth, George Gund Foundation contribute \$50K to 2014 Gay Games [Press release]. Retrieved from http://www.metrohealth.org/news/metrohealth-george-gund-foundation-contribute-50k-to2014-gay-games.

Mirakhmedov, S.M., Jammalamadaka, S.R., \&Ekstrom, M. (2015). Edgewroth expansions for two-stage sampling with applications to stratified and cluster sampling. The Canadian Journal of Statistics,43(4), 578-599.

Mullen, R., Hardy, S., \& Sutton, W. (2014). Sport Marketing (4th Ed.). Champaign: Human Kinetics Publishers.

Niedermier, R. (2015, February 2). Hosting the Gay Games meant more than a one-time economic boost. WKSU. Retrieved from http://www.wksu.org/news/story/41821.

QSR International (2017). Getting started with NVivo 11. Retrieved from http://download.qsrinternational.com/Document/NVivo11/NVivo11-Getting-Started-Guide.pdf.

Rohlin, S.M., \&Greenhalgh-Stanley, N. (2014). The 2014 Gay Games: An economic impact study.[White paper]. Retrieved January 20, 2018 from Gay Games 9:

http://www.gg9cle.com/_CE/pagecontent/Documents/Learn\%20About\%20The\%20Games/Economic\%20Imp act\%20Study\%20for\%20Gay\%20Games\%202014.pdf.

Saldana, J. (2012).The Coding Manual for Qualitative Researchers. London: Sage.

Sandler, D.M. \&Shani, D. (1993). Sponsorship and the Olympic games: The consumers' perspective. Sport Marketing Quarterly, 2(3), 38-43.

Shani, D. (2015). Sport marketing and nonprofit marketing - perfect together. International Review on Public and Nonprofit Marketing, 12(2), 93-95.

Smith, R. (2009, October 7). Cleveland's "square factor" helps land the Gay Games. The Cleveland Plain Dealer. Retrieved from http://blog.cleveland.com/metro/2009/10/clevelands_square_factor_helps.html.

Stotlar, D.K. (2013). Developing Successful Sport Sponsorship Plans. Morgantown, WV: Fitness Information Technology.

Suttell, S. (2015, February 19). Gay Games 9 generated $\$ 6.8$ million in revenue, $\$ 147,000$ in net profit, report says. Crain's Cleveland Business. Retrieved from https://www.crainscleveland.co m/article/20150219/FREE/150219829/gay-games-9-generated-6-8-million-inrevenue-147000-in-net-profitSwaddling, J. (1999). The Ancient Olympic Games. Austin: University of Texas Press.

Symons, C. (2012). The Gay Games: A history. London: Routledge.

The why from sponsors. (n.d.) Federation of Gay Games. Retrieved from http://www.gg9cle.com/donate-sponsor/ sponsors/the-why-from-sponsors/

Thomas, D. (2006). A general inductive approach for analyzing qualitative evaluation data. American Journal of Evaluation, 27(2), 237-246. 
Tsordia, C., Papadimitriou, D., \& Parganas, P. (2018). The influence of sport sponsorship on brand equity and purchase behavior. Journal of Strategic Marketing, 26(1), 85-105.

Wicker, P., \& Breuer, C. (2012). Understanding the importance of organizational resources to explain organizational problems: Evidence from nonprofit sport clubs in Germany. International Journal of Voluntary and Nonprofit Organizations, 24(2), 461-484.

Wilkinson, D. (1993). The event management and marketing institute. Toronto, Canada: The Event Management and Marketing Institute.

Yin, R.K. (2009). Case Study Research: Design and Methods. London: Sage.

Yin, R., Bateman, P., \& Moore, G. (1983). Case studies and organizational innovation: Strengthening the connection. Washington D.C: COSMOS.

Zainal, Z. (2007). Case study as a research method. Jurnal Kemanusiaan, 9, 1-6.

Zullo, R. (2013). Future trends in outsourced marketing within Division I intercollegiate athletics. Journal of Applied Sport Management, 5(3), 24-48. 